|| ISSN(online): 2589-8698 || ISSN(print): 2589-868X ||

International Journal of Medical and Biomedical Studies

Available Online at www.ijmbs.info

NLM (National Library of Medicine ID: 101738825)

Index Copernicus Value 2019: 79.34

Original Research Article

Volume 5, Issue 8; August: 2021; Page No. 05-07

\title{
DESCRIPTIVE STUDY OF POST OPERATIVE INFECTION INOPEN ORTHOPAEDIC INJURIES
}

\author{
Shekh Mohammed Khan ${ }^{1}$, R C Meena ${ }^{2}$, Navendu Ranjan ${ }^{3}$, Uday Raman ${ }^{4}$ \\ ${ }^{1}$ Resident Doctor, Department of Orthopaedics SMS Medical College Jaipur \\ ${ }^{2}$ Senior Professor, Department of Orthopaedics SMS Medical College Jaipur \\ ${ }^{3}$ Resident Doctor, Department of Orthopaedics SMS Medical College Jaipur \\ ${ }^{4}$ Resident Doctor, Department of Orthopaedics SMS medical College Jaipur
}

Article Info: Received 14 May 2021; Accepted 27 July 2021

DOI: https://doi.org/10.32553/ijmbs.v5i8.2056

Corresponding author: Shekh Mohammed Khan

Conflict of interest: No conflict of interest.

\begin{abstract}
Background: In this study, we studied the pattern of bacterial isolates in all cases of open fractures of extremities that came to our hospital.

Methods: This descriptive study was to be conducted on open orthopaedic injuries being admitted to the orthopaedic department, from June 2019 to June 2020 after obtaining institutional ethical committee clearance.

Results: Culture analysis showed an increase in growth of Gram-negative bacteria,namely Pseudomonas aeruginosa (26.3\%) and Escherichia coli (10.5\%) while Gram-positive bacteria were Staphylococcus aureus (52.6\%) and Klebsiella pneumoniae $(10.5 \%)$.

Conclusion: Unlike surgery in other orthopedic areas, the predicting factors for infection in fracture patients were found to be significantly influenced by open fracture rather than the underlying disease or anatomical features of the patient. However, only the correlation with simple open fracture has been confirmed. Therefore, further studies on the cause of open fracture and the mechanism of open fracture are necessary to determine the risk ofinfection.
\end{abstract}

Keywords: Infection, Orthopaedics, Open surgery

\section{Introduction}

The primary function of intact skin is to control microbial populations that live on the skin surface and to prevent underlying tissue from becoming colonized and invaded by potential pathogens. ${ }^{1}$

Exposure of subcutaneous tissue following loss of skin integrity (i.e. wound) provides a moist, warm, and nutritious environment that is conducive to microbial colonization and proliferation. Since wound colonization is most frequently poly-microbial, involving numerous microorganisms that are potentially pathogenic, every wound is at potential risk of becoming infected. ${ }^{2}$

Infection of the surgical site is a severe complication related to fracture treatment, and is associated with increased in morbidity, mortality, and costs. The rate of infection associated with internal fracture fixation may be as high as $3.6 \%$ to $8.1 \%$ for closed fractures and $30 \%$ for open fracture. ${ }^{3}$ This high incidence of post-operative infection in fractures contrasts with a risk of less than $2 \%$ in elective joint reconstruction surgeries. ${ }^{4}$

\section{Material and Methods}

This descriptive study was to be conducted on open orthopaedic injuries being admitted to the orthopaedic department, from June 2019 to June 2020 after obtaining institutional ethical committee clearance.

\section{Study area}

Patients in the department of Orthopaedics in teaching hospitals attached to S.M.S Medical College and hospital.

\section{Study design}

Hospital based Descriptive type of Observational study

\section{Study duration}

Data collection was started first after the approval from institutional research review board and ethical committee upto June 2020 or till sample size was achieved, whichever was earlier. It took another month for follow up and one month for data processing and writing thesis.

\section{Sample size}

As it was a descriptive type of study, sample size was deduced as 1 year cases from June 2019 to 2020.

\section{Study universe}

Open orthopaedic injuries cases attending orthopaedics department of

S.M.S. Medical College Jaipur (Raj), India

Inclusion Criteria -

1. Open orthopaedic injuries 
2. All age group

3. Both sexes

4. Fracture duration less than 1 week after hemodynamic stabilization

5. Patients who are fit for anesthesia and surgery

6. Patients who gave written informed consent and were willing forfollow up and participate in this study.

7. Patients with purulent discharge from incision or drain within a week after surgery and also after few weeks after discharge from hospital of all age groups and both sexes will selected.

\section{Exclusion Criteria-}

1. Pregnancy

2. Uncontrolled Diabetes Mellitus, Hypertension, Psychiatric illness, Acute Myocardial infarction less than 1 year.
3. Periprosthetic fractures.

4. Associated major visceral injury.

5. Use of antibiotics after diagnosis of infection.

6. Implantation done through already infected wound

\section{Statistical analysis}

The data was coded and entered into Microsoft Excel spreadsheet. Analysis was done using SPSS version 20 (IBM SPSS Statistics Inc., Chicago, Illinois, USA) Windows software program. Descriptive statistics included computation of percentages, means and standard deviations. Level of significance was set at $P \leq 0.05$.

\section{Results}

Age 20-30 years patients were 25\%, age 30-40 years patients were $36 \%$ and age $40-50$ years patients were $38 \%$. Male $(87 \%)$ patients were found higher as compared to female patients(13\%).

Table 1: Type of fracture wise distribution of the study

\begin{tabular}{|l|l|l|}
\hline & Frequency & Percent \\
\hline OPEN FRACTURE DISLOCATION ANKLE & 3 & 3.0 \\
\hline OPEN FRACTURE DISLOCATION WRIST & 1 & 1.0 \\
\hline OPEN FRACTURE DISTAL END RADIUS & 1 & 1.0 \\
\hline OPEN FRACTURE DISTAL FEMURE & 6 & 6.0 \\
\hline OPEN FRACTURE DISTAL WRIST & 1 & 1.0 \\
\hline OPEN FRACTURE FEMURE SHAFT & 1 & 1.0 \\
\hline OPEN FRACTURE HUMERUS & 4 & 4.0 \\
\hline OPEN FRACTURE LEG BONE & 65 & 65.0 \\
\hline OPEN FRACTURE OLECRANON & 3 & 3.0 \\
\hline OPEN FRACTURE SHAFT OF FEMURE & 10 & 10.0 \\
\hline OPEN FRACTURE ULNA & 1 & 1.0 \\
\hline OPEN FRACTUTRE BOTH BONE FOREARM & 4 & 4.0 \\
\hline TOtal & 100 & 100.0 \\
\hline
\end{tabular}

Open leg bone fracture was found higher $65 \%$ followed by femur shaft $(10 \%)$, distal femure $(6 \%)$, forearm fracture $(4 \%)$ and humerus fracture $(4 \%)$

Table 2: Microorganism wise distribution of the study

\begin{tabular}{|l|l|l|}
\hline & Frequency & Percent \\
\hline Absent & 81 & 81 \\
\hline Present & 19 & 19 \\
\hline Total & 100 & 100.0 \\
\hline
\end{tabular}

$19 \%$ of patients had positive culture report.

Table 3: Microorganism wise distribution of the study

\begin{tabular}{|l|l|l|}
\hline & Frequency & Percent \\
\hline E. coli & 2 & 10.5 \\
\hline Klebsiella pneumoniae & 2 & 10.5 \\
\hline Pseudomonas aeruginosa & 5 & 26.3 \\
\hline Staphylococcus aureus & 10 & 52.6 \\
\hline Total & 19 & 100.0 \\
\hline
\end{tabular}


Culture analysis showed an increase in growth of Gramnegative bacteria,namely Pseudomonas aeruginosa (26.3\%) and Escherichia coli (10.5\%) while Gram-positive bacteria were Staphylococcus aureus (52.6\%) and Klebsiella pneumoniae $(10.5 \%)$.

\section{Discussion}

The management of open fractures is challenging. Infection is a major complication of open fractures. The choice of prophylactic antibiotics for open fractures was important for the management of open fracture. However, the previous studies showed controversial results of optimal therapy. One major reason was that hospital acquired pathogens were increasingly present in the infection of open fractures and the antibiotic resistance of nosocomial pathogens varied among different institutes.

It has been observed that most open fracture infections are caused by Gram-negative rods and Gram-positive staphylococci, therefore antibiotics should cover both types of organism. ${ }^{5}$ However, recently, Methicillinresistant S. aureus has been found to be associated with open lower limb fractures in some series. The optimal antibiotic regimen to combat the infection rate with open fracture is not clear from the literature. ${ }^{6}$ It is important that, in the setting of open fracture, antibiotics should not be considered as prophylactic therapy. As infection commonly occurs in open fractures not treated with antibiotics, their administration should, better, be viewed as therapeutic. Many studies have shown that all open fractures should be treated with combination of a first-generationcephalosporin and an aminoglycoside. It has also been observed that a significant percentage of late infections occur with hospital-acquired organisms, suggesting that inoculation of pathogens occurs subsequent to the initial injury. ${ }^{8}$

The constantly changing local wound ecology and sampling variationsled to the proposition of different ideas by different authors in the orthopedic literature. Based on the types of organism causing infection compared with those on early wound cultures, several authors have proposed that many infections of open fracture wounds are nosocomial. ${ }^{9}$ Wound contamination occurs with both Gram-positive and Gram- negative microorganism; therefore, the antimicrobial regimen should be effective against both the types of pathogen. ${ }^{10}$

Unlike surgery in other orthopedic areas, fracture surgery should take intoaccount the energy impairment experienced by the patient at the time of injury. In other elective surgeries, there are no additional injuries other than surgical damage, but this is not the case with fracture surgery.
Prevalence of microorganism was $19 \%$ in this study. Agarwal D (2015) et al found that prevalance was $34.2 \%$ (24 patients out of 70). They noticed that Coagulasenegative S. aureus was the most common Gram-positive bacteria isolated with Acinetobacter calcoaceticusbaumannii complex as the most common Gram-negative bacteria.

\section{Conclusion}

Unlike surgery in other orthopedic areas, the predicting factors for infection in fracture patients were found to be significantly influenced by open fracture rather than the underlying disease or anatomical features of the patient. However, only the correlation with simple open fracture has been confirmed. Therefore, further studies on the cause of open fracture and the mechanism of open fracture are necessary to determine the risk ofinfection.

\section{References}

1. Dai T, Huang Y-Y, Sharma SK, Hashmi JT, Kurup DB, Hamblin MR: Topical antimicrobials for burn wound infections. Recent Pat Antiinfect Drug Discov 2010;5(2):124-151.

2. Trampuz A, Zimmerli W. Diagnosis and treatment of infections associated with fracture-fixation devices. Injury. 2006;37(Suppl 2):S59-66.

3. Campoccia D, Montanaro L, Arciola CR. The significance of infection related to orthopedic devices and issues of antibiotic resistance. Biomaterials 2006;27(11):2331-9.

4. Tiwari HK, Sen MR. Emergence of vancomycin resistant Staphylococcus aureus from a tertiary carehospital from northern part of India. BMC Infect Dis $2006 ; 6:: 156$.

5. Lee J. Efficacy of cultures in the management of open fractures. Clin OrthopRelat Res 1997;339:715

6. Griffin M, Malahias $\mathrm{M}$, Khan $\mathrm{W}$, Hindocha S. Update on the management of open lower limb fractures. Open Orthop J 2012;6:571-7.

7. Zalavras CG, Patzakis MJ. Open fractures: Evaluation and management. J Am AcadOrthopSurg2003;11:212-9.

8. Zalavras CG, Patzakis MJ, Holtom PD, Sherman R. Management of open fractures. Infect Dis Clin North Am 2005;19:915-29

9. Ikem IC, Oginni LM, Bamgboye EA, Ako-Nai AK, Onipede AO. The bacteriology of open fractures in Ile-Ife, Nigeria. Niger J Med 2004;13:359-65 